\title{
Flexibility of Red Chili Supply Chain in Panjatan District Kulon Progo Regency
}

\author{
Karisma Damayanti ${ }^{1, *}$, Susanawati ${ }^{2}$, Muhammad Fauzan ${ }^{3}$ \\ ${ }^{1,3}$ Department of agribusiness, Faculty of Agriculture, Universitas Muhammadiyah Yogyakarta, Indonesia \\ ${ }^{2}$ Department of agribusiness, Faculty of Agriculture, Universitas Muhammadiyah Yogyakarta, Indonesia \\ ${ }^{*}$ Corresponding author. Email: karisma.d.fp17@mail.umy.ac.id
}

\begin{abstract}
Measuring the flexibility of the red chilli supply chain is very necessary to determine how flexible the supply chain is to changes and fluctuation that may be faced by each red chilli supply chain actor in Panjatan District. The purpose of this studyis to describe the structure of supply chain relationships based on the actors and their activities and to analysis the flexibility of red chilli supply chain in Panjatan District, Kulon Progo Regency. Kulon Progo Regency was chosen deliberately as the research location because it has highest level of red chilli production in the Special Region of Yogyakarta. Sampling in this study was carried out in several stages starting from Panjatan District, Garongan Village, and Sub-Village 1 and 3. Garongan village was chosen as the sampling location because in 2019 it had the largest number and member of the auction market among other village. The determination of farmer respondents was carried out by purposive sampling method of 80 people. Respondents other than farmers that is 2 auction market manager, 2 district-level collectors, 1 regency-level wholesaler, and 4 regency-level retailers were determined by the snowball sampling method. The method for measuring flexibility is Performance Measurement System (PMS). The result of this research is showed that the structure of the red chili supply chain relationship in Panjatan District, Kulon Progo Regency consist of 2 chains that is chains 1 formed by 5 actors and chain 2 formed by 4 actors and having activities started from red chili cultivation, sorting, grading, weighing, packaging, pricing, bidding, transportation, shipping update information on price and quantities of red chilies, sales, purchase, receiving payments, and making payments. The result of the supply chain flexibility is showed that chain 2 more flexible than chain 1 ..
\end{abstract}

Keywords: flexibility, supply chain, red chili,

\section{INTRODUCTION}

Indonesia's economic development cannot be separated from the agricultural sector. The agricultural sector has an important role in maintaining stability for other sectors. According to Tambunan (2003) the agricultural sector become a leading sector for other sectors. Various sectors in agriculture are developed to be able to contribute to economic development. One of the sub-sectors in agriculture which plays a role in economic development in Indonesia is the horticulture sub-sector. One of commodities to be concern is Red Chilli

Red Chilli (Capsicum annuum L.) is a woody herbaceous plan, and the fruit has spicy taste caused containing of capsaicin. In Indonesia red chilli is cultivated as an annual crop on former rice fields and dry land or moor. The potential yield of red chilli is around $12-20 \mathrm{t} / \mathrm{ha}$ (Sumarni $\&$ Muharam, 2005). If properly cultivated and cultivation of red chilli is successful it will generate big profit for farmers (Sumarni \& Muharam, 2005). Sumarni \& Muharam (2005) stated that red chilli is one of the vegetable commodities that have important role in Indonesia, both as a commodity for consumption or as an export commodity. The consumption of red chilli shows an increasing pattern from year to year
(Eliyatiningsih \& Mayasari, 2019). Increasing consumption of red chilli make the demand for red chilli to increase. In activities fulfilment of red chilli demand in various regions in Indonesia, the supply of red chilli needs to be done as well as possible so that the red chilli needs in all regions can be fulfilled. From the 12 sub-districts in Kulon Progo Regency, the largest red chilli production is in Panjatan District with total production in 2018 was $10,848,700$ kilograms (BPS, 2019)

Table 1. Red Chili Production in Kulon Progo Regency in 2016 - 2018 (kilograms)

\begin{tabular}{|c|c|c|c|}
\hline \multirow{2}{*}{ Sub-District } & \multicolumn{3}{|c|}{ Red Chili Production } \\
\hline & 2016 & 2017 & 2018 \\
\hline Temon & 931 & 1.772 .100 & 4.299 .900 \\
\hline Wates & 2.357 & 5.351 .000 & 5.972 .900 \\
\hline Panjatan & 6.434 .300 & 9.403 .900 & 10.484 .700 \\
\hline Galur & 29.700 & 1.783 .500 & 2.377 .400 \\
\hline Lendah & 97.000 & 583.000 & 1.077 .600 \\
\hline Sentolo & 236 & 170.300 & 252.100 \\
\hline Pengasih & 136 & 510.800 & 425.300 \\
\hline Kolkap. & 35.000 & 201.000 & 194.600 \\
\hline Giximulyo & 5.600 & 15.200 & 62.600 \\
\hline Nanggulan & 31.800 & 290.500 & 15.400 \\
\hline Kalibawwang & 62.000 & 88.700 & 173.000 \\
\hline Samigaluh & 8.400 & 14.800 & 26.600 \\
\hline TOTAL & 20.160 & 20.184 .800 & 25.362 .100 \\
\hline
\end{tabular}

Source : BPS (2019)

One of the regency that are the main suppliers of red chilli in the province Special Region of Yogyakarta is Kulon 
Progo with an average red chilli production in the period between 2014 - 2017 was the most among other districts in the DIY region with an average of $17,380.93$ tons (BPS, 2019). Based on Table 1 the largest of red chilli production is in Panjatan Dsitrict with the total production in 2018 is 10,848,700 kilogram (BPS, 2019). This many results do not guarantee that the income obtained farmers also large it because various factors. One of the factors that can affecting of the income received by farmers is the distribution of red chilli.

On the distribution process the actors involved will know about product flow, money flow, and information flow. However farmer on generally still do not understand how the distribution flow of red chilli resulting from. Concept of the supply chain becomes necessary to know so that supply chain actors understand the product flow, money flow, and information flow. Supply Chain is a concept in which there is a related regulatory system with product flow, information flow, and money flow (Tubagus et al., 2016).

In the supply chain process certainly there are various obstacles that occur when this happens in the field, agriculture product are no exception in this case red chilli. The obstacles that occur in red chilli supply chain process in Panjatan District, Kulon Progo Regency is related to the characteristic of red chilli which is an agricultural product. According to Mareta \& Nur (2011) generally agriculture product are known to have characteristic that is the product is perishable and requires large storage space. This characteristic will affect supply and red chilli customer satisfaction. As a result, the supply chain must be able to adapt the environmental changes and the quality demand of red chilli.

Chairia et al. (2010) stated that the total of need increasing or the demand of red chilli will affect in increasing of production so the supply will also increase. Increasing total of red chilli offered is influenced by many things such as red chilli price, input price production, and harvested area of red chilli Chairia et al. (2010). According to Kustiari et al. (2018)stated that the prices of agricultural commodities especially horticulture always fluctuated and tend to increase. This will affect in the performance of red chilli supply chain. Performance measurement system is needed for determine the response of red chilli supply chain to the environmental changes and the demand consumer of red chilli quality. According to Aramyan (2007) performance supply chain of agricultural product can be seen from Efficiency, Responsibility, Flexibility, and Food Quality.

The occurrence problems in the red chilli distribution process such as change in fluctuating red chilli prices, damage to red chillies cause decrease in the quality of red chilli, as well as an inappropriate quantity the supply of red chilli distributed will cause dissatisfaction customers for red chilli. Increased consumer demand for quality, quantity, and continuity of red chilli must be balanced with availability of appropriate red chilli so that consumers feel satisfied. In addition to red chilli distribution process certainly be able to fulfil the number need of red chilli and must be on time to reach the hands of consumers. This research was conducted for describe the structure of supply chain relationships based on the actors and their activities and to analysis the flexibility of red chilli supply chain in Panjatan District, Kulon Progo Regency.

\section{LITERATURE REVIEW}

In this research use Performance Measurement System (PMS) based on Aramyan (2007). PMS method according to Aramyan (2007) is the performance measurement system that enable a companies to monitor the relevant performance indicator from a product, services, and production process within the appropriate timeframe. PMS method used because this method is able to inform decision makers whether the performance is in accordance with their goals. This method also inform the decision make whether the customer is satisfied with the product and where improvement need to be made. The integrated PMS measurement will provide a more comprehensive measurement from entire of supply chain performance.

Aramyan (2007) state that indicator in the PMS method used for agriculture supply chain performance measurement is group become four categories that is efficiency, flexibility, responsibility, and food quality.

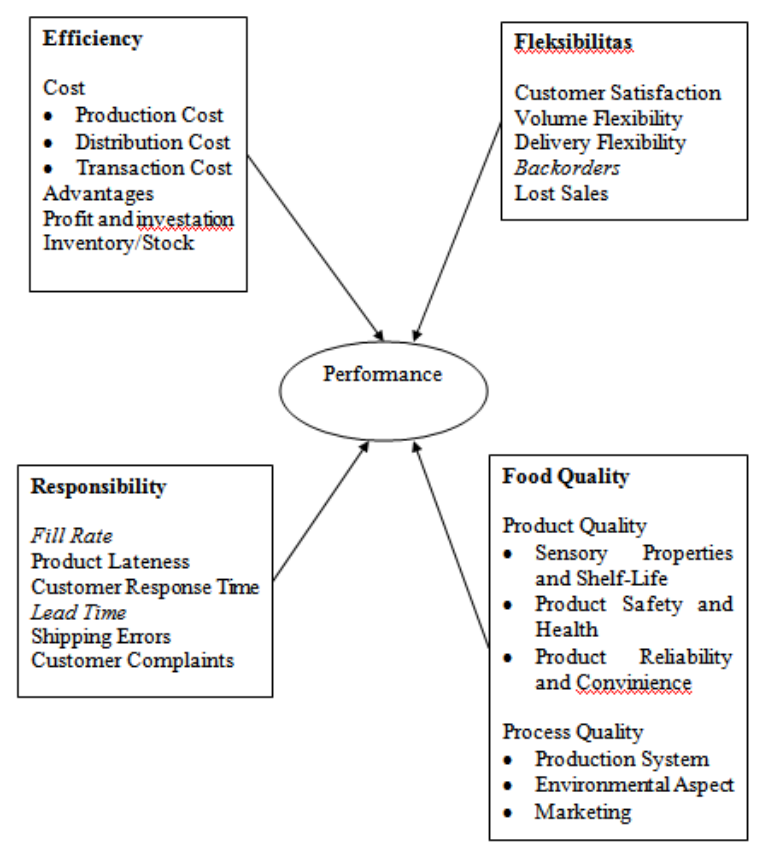

Figure 1 Indicators of Supply Chain Performance Measurement

Source : Aramyan (2007) 
Supply chain flexibility has an important role in success for it self, especially in companies that have very high uncertainty (Kharis et al., 2011). Flexibility is the responsibility of each element in the supply chain both in internal or external companies such as suppliers, distributors, retailers, or actors that assisting in the provision of information (Swafford et al., 2000)

Swafford et al. (2000) mentioned that the components of flexibility involve : product development flexibility, sourcing flexibility, manufacturing flexibility, and logistics flexibility. product development flexibility is ability to development the various product and/or product improvement in response customer or market need, or utilize market opportunity or use the technology improvement. Sourcing flexibility is purchasing function ability to response in timely manner and the effective cost for change purchasing component requirement. Manufacturing flexibility is manufacture ability to suitable the ability for produce the product that have a certain quality in the effective time and cost to response the change of product characteristic, ingredient supply, and demand or apply technology process improvement. Logistic flexibility is ability to adapted, on the time, and ways to save the cost, flow control process and saving ingredient, finished good, service, and information related from origin to the goals as response to changing the environmental condition.

According to Aramyan (2007) flexibility indicates the degree of supply chain response to the changing environment. Indicator in flexibility include customer satisfaction, volume flexibility, delivery flexibility, backorders, and lost sales.

Customer satisfaction is related with customer that shows the extent to which customers are satisfied with the product or services is provided. Volume flexibility is ability to changing output level from the resulting product. Delivery flexibility is companies ability to changing planned delivery schedule. Backorders is orders that are not currently in stock for available product, but is being reordered (in this case the customer disposed to wait until supplies are coming back) and will be available at the later time.

\section{METHOD}

The research method used in this study is analysis descriptive. Descriptive analysis method is used to analyze by describing the data that has been collected as it is without intending to draw conclusions applicable to the general public or generalization (Sugiyono, 2010). Descriptive analysis method will help researchers to explain the Flexibility of Red Chilli Supply Chain in Panjatan District Kulon Progo Regency. The research location was chosen deliberately in Kulon Progo Regency because it has highest production of red chilli in the Special Region of
Yogyakarta. Taking the sample in this research was carried out in several stage with the following:

(1) First stage is carried out at the sub-district stage that was deliberately selected in Panjatan District because it has a high level production of red chilli in 2018 with the amount $10,484.7$ tons.

(2) Second stage was carried out in village level and Garongan Village was selected because it has the largest number of auction markets and the auction market members is any than the other village.

(3) Third stage is determination at the sub-village in the Garongan Village and sub-villages 1 and 3 are selected. From total of auction market members in the Garongan village was taken 80 farmers to become respondents with the provision still actively selling red chilli to the auction market and cultivating red chilli as the main crop. Farmer respondents were determined by purposive sampling method.

(4) Determination respondents such as 2 of the Garongan Village auction market managers, 2 Collectors at the district level, 1 wholesaler at the regency level, and 4 retailers at the regency level using snowball sampling method.

The data analysis technique used in this research is descriptive analysis and flexibility analysis. Descriptive analysis is used to analyze the actors was carried out in red chili supply chain process started from farmers at the Garongan Village, Panjatan District, Kulon Progo Regency until end consumers at the Kulon Progo Regency. This analysis also will explained various activities which is conducted by the actors of red chili supply chain in Panjatan District, Kulon Progo Regency and will illustrated in the structure of the red chilli supply chain network.

Analysis flexibility is carried out by Performance Measurement System (PMS) method based on measurements according to Aramyan (2007) with the aim of knowing the flexibility in the red chilli supply chain in Panjatan District, Kulon Progo Regency. The analysis is do on each indicator that is customer satisfaction, volume flexibility, and delivery flexibility.

\subsection{Customer Satisfaction}

Customer satisfaction is analyzed based on indicators that is price, cleanliness, damage rate, freshness, and on time delivery. To find out the high and low level of customer satisfaction with red chili then carried out categorization. The categories used in customer satisfaction are Low, Medium, and High. Categorization is done using Sturgess Formulas as follows.

$Z=\frac{X-Y}{K}$ 
Information :

$\mathrm{Z}=$ Class Interval

$\mathrm{X}=$ Higher Score

$\mathrm{Y}=$ Lower Score

$\mathrm{K}=$ Total of Categories

Based on that formulas it can be seen that class interval in the indicator of customer satisfaction is :

$$
\begin{array}{ll}
\text { Score categories of each indicators : } & \text { Score categories of all indicators : } \\
Z=\frac{5-1}{3}=1,33 & Z=\frac{25-5}{3}=6,67
\end{array}
$$

Table 2. Categorization Of Customer Satisfaction

\begin{tabular}{ll}
\hline \multicolumn{1}{c}{ Average Score } & \multicolumn{1}{c}{ Customer Satisfaction Categories } \\
\hline Each Indicators & \\
\hline $1,00-2,33$ & Low \\
$2,34-3,67$ & Medium \\
$3,68-5,00$ & High \\
\hline All Indicators & \\
\hline $5,00-11,67$ & Low \\
$11,68-18,35$ & Medium \\
$18,36-25,00$ & High \\
\hline
\end{tabular}

If the level of customer satisfaction is in high category, the red chili supply chain can be said to be flexible. This research is correspondent with the research that conducted by Purnomo (2018) which state that the excellence of flexible supply chain is to increase customer satisfaction.

\subsection{Volume Flexibility}

Volume flexibility is calculated by the indicator of the difference total of demand red chili in kilograms and the total of sold red chili in kilograms in one season. To find out there are whether or not gap in volume flexibility at the red chili supply chain in Panjatan District, Kulon Progo Regency then will be categorization. The categories in volume flexibility that is no gap and there are gap and will be calculated based on Sturgess Formulas.

$Z=\frac{X-Y}{K}$

Information :

$\mathrm{Z}=$ Class Interval

$\mathrm{X}=$ Higher Score

$\mathrm{Y}=$ Lower Score

$\mathrm{K}=$ Total of Categories

Based on that formulas it can be seen that class interval in the indicator of volume flexibility is :

Indicator score categories:

$Z=\frac{2-1}{2}=0,50$

\begin{tabular}{|c|c|}
\hline Average Score & Volume Flexibility Categories \\
\hline $1,00-1,50$ & There are gap \\
\hline $1,51-2,00$ & No gap \\
\hline
\end{tabular}

Table 3. Categorization Of Volume Flexibility

If no gap in volume flexibility the red chili supply chain can be said to be flexible. This is according with the research which is conducted by Rosindiyanto (2012) which state that the greater value of weighted gap of a criterion it means increasingly necessary to make improvement to this criteria.

\subsection{Delivery Flexibility}

Delivery flexibility is analyze with difference between promised delivery time with actual delivery time. To find out suitable or not suitable delivery time in delivery flexibility the red chili supply chain actors in Panjatan District, Kulon Progo Regency then will categorization. The categories in delivery flexibility is suitable with the delivery time and not suitable with the delivery time and will be calculated based on Sturgess Formulas.

$Z=\frac{X-Y}{K}$

Information :

$\mathrm{Z}=$ Class Interval

$\mathrm{X}=$ Higher Score

$\mathrm{Y}=$ Lower Score

$\mathrm{K}=$ Total of Categories

Based on that formulas it can be seen that class interval in the indicator of delivery flexibility is :

Indicator score categories:

$$
\mathrm{Z}=\frac{2-1}{2}=0,50
$$

Table 4. Categorization Of Delivery Flexibility

\begin{tabular}{ll}
\hline \multicolumn{1}{c}{ Average Score } & \multicolumn{1}{c}{ Delivery Flexibility Categories } \\
\hline $1,00-1,50$ & Not suitable with the delivery time \\
$1,51-2,00$ & Suitable with the delivery time \\
\hline
\end{tabular}

If suitable with the delivery time that occurs in delivery flexibility, the red chilli supply chain can be said to be flexible. This is according to research that conducted by Purnomo (2018) which state that the excellence of flexible supply chain is able to reduce total of late orders. 


\section{RESULT AND DISCUSSION}

\subsection{Relationship Structure of The Red Chili Supply Chain}

The supply chain structure describes the relationship between each supply chain actor and its role (Aris Munandar et al., 2020). In the research conducted by Tubagus et al. (2016) there are five actors who play an active role in the supply chain of cayenne pepper commodities in the Kumelembuai Village namely chili farmers, collectors, market traders, chili retailers, and consumers.

In this research relationship structure of the red chili supply chain in Panjatan District Kulon progo Regency describe the product flow, money flow, and information flow of the red chili from farmer at the Garongan Village, Panjatan District to end consumer at the Kulon Progo Regency. Structure of the red chili supply chain in Panjatan District can be known based on the actors involved the red chili supply chain and various activities they do.

Structure of the red chili supply chain in Panjatan District is formed from 6 actors namely farmer in Garongan Village, auction market at the Garongan Village, collectors at the district level, wholesalers at the regency level, retailers at the regency level, and end consumers in Kulon Progo Regency.
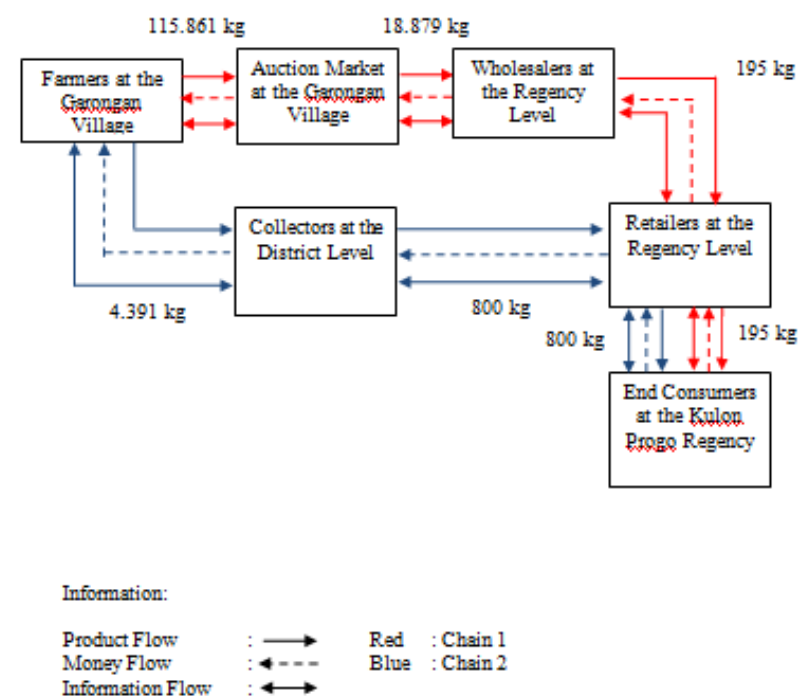

Figure 2 Relationship Structure of Red Chili Supply Chain in Panjatan District

Based on the Figure 2 it can be seen that the structure of red chili supply chain in Panjatan District consist of 2 chain that is:

1. Farmers at the Garongan Village- Auction Market at the Garongan Village - Wholesalers at the Regency Level Retailers at the Regency Level - End consumers at the Kulon Progo Regency.

2. Farmers at the Garongan Village - Collectors at the District Level - Retailers at the Regency Level - End consumers at the Kulon Progo Regency.
During one growing season, farmers in Garongan Village produce red chili as much as $120,252 \mathrm{~kg}$. In the first supply chain consist 5 actors. Product flow of red chili flows from farmers at the Garongan Village Panjatan District to the auction market at the GaronganVillage. Total of red chili that on sale by farmers to auction market at the Garongan Village for one growing season as much as $115,829 \mathrm{~kg}$ or $96.35 \%$ of the red chili produced by farmer. In the first planting season of 2020 which starts in March until August there are 2 active auction market, namely Bangunkaryo auction market (K1) and Ngudi Hasil auction market (K5).

Total of $96,982 \mathrm{~kg}$ or $83.71 \%$ of red chili from the auction market at the Garongan Village are channeled outside of Kulon Progo Regency area. While as many as $18,879 \mathrm{~kg}$ or $16.29 \%$ of red chili are purchased by wholesaler at the regency level. A total of 18,684 or $98.97 \%$ distributed by wholesalers outside the city and as many as $195 \mathrm{~kg}$ or $1.03 \%$ of outcome from auction market are distributed to retailers at the regency level and to be distributed to end consumers at the Kulon Progo Regency namely Wates Market. Money flow will flow from end consumers at the Kulon progo Regency to farmer at the GaronganVillage. Information flow will flow two-way direction from farmers at the Garongan Village to the end consumers at the Kulon Progo Regency vice versa.

While the second supply chain is formed by 4 actors. The red chilies flow from farmers at the Garongan Village to the collectors at the district level with total of red chili as many as $4,391 \mathrm{~kg}$ or $3.65 \%$ from the outcome of red chili that produced by farmers in the last growing season. From collectors at the district level red chili will distributed to retailers at the regency level as many as $800 \mathrm{~kg}$ or $18.22 \%$ while as many as $3,591 \mathrm{~kg}$ or $81.78 \%$ will distributed by collectors at the district level to the wholesaler at the regency level and the next will be distributed at the outside of Kulon Progo Regency area. From retailers at the regency level the red chili will distributed to end consumers at the Kulon Progo Regency that is Wates market and Ngentakrejo market. The money will flow from end consumers at the Kulon Progo regency to the farmers at the Garongan Village. The information will flow from farmers at the Garongan Village until end consumers at the Kulon Progo Regency vice versa.

The relationship structure of the red chili supply chain also is formed by the activity that carried out by supply chain actors. As shown by Figure 3 the activities carried out by red chili supply chain actors in Panjatan District, Kulon Progo Regency starting from red chili cultivation, sorting, grading, weighing, packaging, pricing, bidding price, transportation, delivery, update information of price and quantity of the red chili, selling, purchasing, receiving payment, and making payment. 


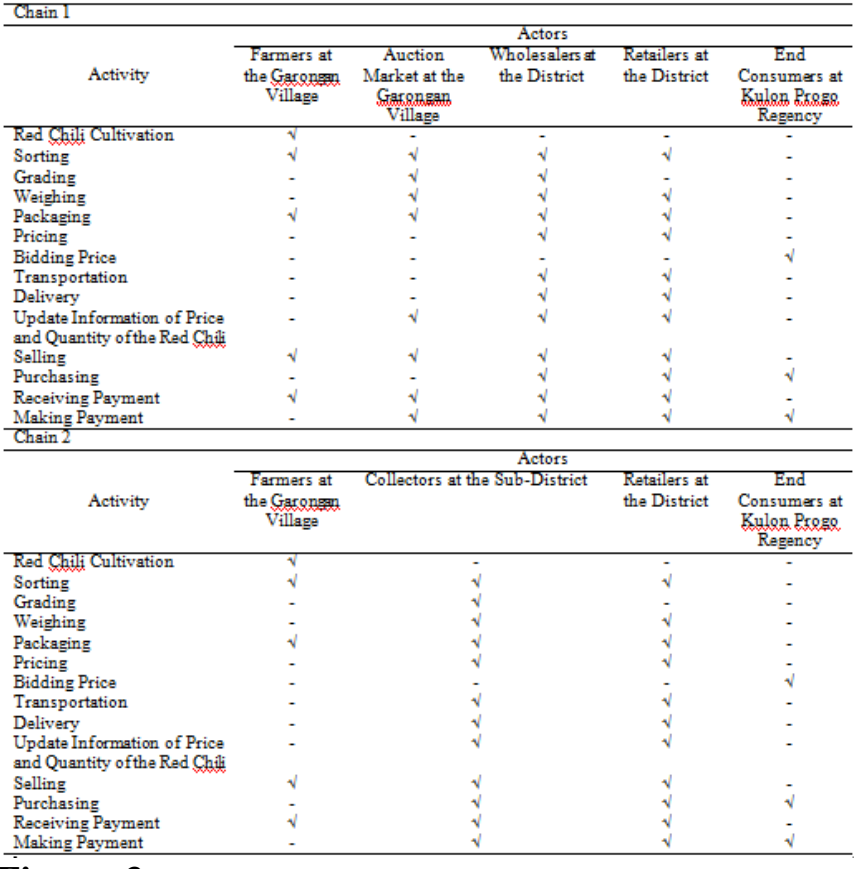

Figure 3 Activities of Supply Chain Actors in Panjatan District

\subsection{Flexibility of Red Chili Supply Chain}

Flexibility is a characteristic that must owned by supply chain and become responsibility of every element in the supply chain both from the company's internal and external start from suppliers, distributors, retailers (Soejanto \& Nursubiyantoro, 2013). The flexibility of supply chain describe the extent of supply chain can respond a changing environment and a extraordinary demand of customer services (Aramyan, 2007).

Research about flexibility of supply chain that is conducted by Kharis et al. (2011) shows that based on weighted abilities and needs, dimensions of delivery and production systems show a balanced state that is between needs/capabilities possessed and flexibilities are comparable. While the dimensions of the supplier and product design show a balanced state that the needs and capabilities are comparable that is low needs can to be balanced with low capabilities. Five big priority which still need to be improved based on GAP in order from the largest to the lowest that is delivery of request information are easily and quickly (delivery system), fulfillment of urgent requests (delivery system), changing delivery schedule quickly (delivery system), delivery with flexible quantity (delivery system), production with flexible quantity (production system).

In this research, the measurement of flexibility will be seen in two red chilli supply chain formed in Panjatan District, Kulon Progo Regency. The indicator used to measurement include customer satisfaction, volume flexibility, and delivery flexibility.

\begin{tabular}{|c|c|c|c|c|c|c|}
\hline \multicolumn{7}{|l|}{ Chain 1} \\
\hline Indicators & $\begin{array}{c}\text { Farmers at } \\
\text { the } \\
\text { Garongan } \\
\text { Village }\end{array}$ & $\begin{array}{l}\text { Auction } \\
\text { Market at the } \\
\text { Garongan } \\
\text { Village }\end{array}$ & $\begin{array}{l}\text { Wholesaler at } \\
\text { the District } \\
\text { Level }\end{array}$ & $\begin{array}{c}\text { Retailers at } \\
\text { the District } \\
\text { Level }\end{array}$ & Total & Average \\
\hline $\begin{array}{l}\text { Customer } \\
\text { Satisfaction }\end{array}$ & 19,85 & 19,00 & 14,00 & 20,00 & 72,85 & 18,21 \\
\hline $\begin{array}{l}\text { Volume } \\
\text { Flexibility }\end{array}$ & 2,00 & 2,00 & 2,00 & 2,00 & 8,00 & 2,00 \\
\hline $\begin{array}{l}\text { Delivery } \\
\text { Flexibility }\end{array}$ & 1,99 & - & - & - & 1,99 & 1,99 \\
\hline \multicolumn{7}{|l|}{ Chain 2} \\
\hline Indicators & $\begin{array}{c}\text { Farmers at } \\
\text { the } \\
\text { Garongan } \\
\text { Village }\end{array}$ & $\begin{array}{l}\text { Collectors at } \\
\text { the Sub- } \\
\text { District Level }\end{array}$ & \multicolumn{2}{|c|}{$\begin{array}{l}\text { Retailers at the } \\
\text { District Level }\end{array}$} & Total & Average \\
\hline $\begin{array}{l}\text { Customer } \\
\text { Satisfaction }\end{array}$ & 20,00 & 16,00 & \multicolumn{2}{|c|}{19,67} & 55,67 & 18,56 \\
\hline $\begin{array}{l}\text { Volume } \\
\text { Flexibility }\end{array}$ & 2,00 & 2,00 & \multicolumn{2}{|c|}{2,00} & 6,00 & 2,00 \\
\hline $\begin{array}{l}\text { Delivery } \\
\text { Flexibility }\end{array}$ & 2,00 & - & \multicolumn{2}{|c|}{ - } & 2,00 & 2,00 \\
\hline
\end{tabular}

Information : - : delivery is not occurs

Figure 4 Flexibility of Red Chili Supply Chain in Panjatan District Kulon Progo Regency

Based on the Figure 4 can be seen on the customer satisfaction indicator chain 2 more flexible than chain 1 . It because average score obtained in chain 2 as many as 18.56 which is include in high category while on the chain 1 average score which obtained is 18.21 and include medium category. This is accordance with the research conducted by Purnomo (2018) which states that the advantage of a flexible supply chain is it can increase customer satisfaction.

At the volume flexibility the two supply chain equally flexible. It because average score obtained in two supply chain is 2.00 with no gap category. It appropriate with the research conducted by Rosindiyanto (2012) which state that the greater value of weighted gap a criterion, it means more need to fixed at the criterion.

At the delivery flexibility between chain 1 and chain 2 equally flexible. It because the delivery of red chilli is on time. However chain 2 is more flexible than chain 1 because has higher average than chain 1 . This is suitable with the research conducted by Soejanto \& Nursubiyantoro (2013) which state that the excellent of flexible supply chain it can decrease late order.

Total of actors in a supply chain does not determine the flexibility in the supply chain. It means that the fewer actors is involved in supply chain is not necessarily the supply chain can be said flexible. Flexibility level for each supply chain is not necessarily same. This can be influenced by the level of uncertainty for the demand for a product that experienced by a supply chain (Soejanto \& Nursubiyantoro, 2013). Stevenson \& Spring (2007) stated that flexibility is something that are multi-dimensional, if flexible in one dimensional unit it does not mean that the other units will be flexible. Two supply chains can equally flexible with a different way. 


\section{CONCLUSION AND RECOMMENDATION}

\subsection{Conclusion}

Based on the results of data analysis in this research conclusion can be drawn that is:

(1) The structure of red chili supply chain in Panjatan District consist of 2 chain that is chain 1 is formed by 5 actors and chain 2 is formed by 4 actors and having activities started from red chili cultivation, sorting, grading, weighing, packaging, pricing, bidding, transportation, shipping update information on price and quantities of red chilies, sales, purchase, receiving payments, and making payments.

(2) Chain 2 more flexible based on customer satisfaction indicator and delivery flexibility.

\subsection{Recommendation}

Based on the result of this research there are recommendation given as material consideration to expedite the red chilli supply chain in Panjatan District, Kulon Progo Regency that is necessary more attention to damaged level, cleanliness, and freshness of red chili in order no to cause customer dissatisfaction. In addition, it is also necessary to pay attention the delivery of red chili so that the red chili is stay fresh until to the customer.

\section{REFERENCES}

[1] Aramyan, L. . (2007). Measuring Supply Chain Performance in the Agri-Food Sector. Wageningen University.

[2] Aris Munandar, M., Irfan, \& Jaya, R. (2020). Analisis Struktur dan Nilai Tambah Pada Rantai Pasok Beras di Kabupaten Aceh Timur. Jurnal Teknologi Dan Industri Pertanian Indonesia, 12(02).

[3] BPS. (2019). Kabupaten kulon Progo Dalam Angka 2019.

[4] Chairia, Salmiah, \& Sihombing, L. (2010). Analisis Permintaan dan Penawaran Cabai Merah di Provinsi Sumatera Utara. Journal of Agriculture and Agribusiness Socioeconomics, 5(1), 95145., 1-12. file:///C:/Users/HP/Documents/KEDELAI/RURY/AN ALISIS_FAKTOR-

FAKTOR_YANG_MEMENGARUHI_IMPOR_KED E.pdf

[5] Eliyatiningsih, E., \& Mayasari, F. (2019). Efisiensi Penggunaan Faktor Produksi Pada Usahatani Cabai Merah di Kecamatan Wuluhan Kabupaten Jember. Jurnal Agrica, 12(1), 7. https://doi.org/10.31289/agrica.v12i1.2192

[6] Kharis, A., Hidayat, R., \& Utami, I. D. (2011). Fleksibilitas Supply Dengan Pendekatan. Jurnal Teknologi, 4, 69-77.
[7] Kustiari, R., Sejati, W. K., \& Yulmahera, R. (2018). Integrasi Pasar dan Pembentukan Harga Cabai Merah di Indonesia. Jurnal Agro Ekonomi, 36(1), 39. https://doi.org/10.21082/jae.v36n1.2018.39-53

[8] Mareta, D. T., \& Nur, S. (2011). Pengemasan Produk Sayuran Dengan Bahan Kemas Plastik Pada Penyimpanan Suhu Ruang Dan Suhu Dingin. Mediagro, 7(1), 26-40.

https://www.publikasiilmiah.unwahas.ac.id/index.php/ Mediagro/article/download/530/652

[9] Purnomo, A. (2018). Model Pengukuran Fleksibilitas. Streamlining Integrated Supply Chain Management as the New Frontier of Competitive Advantage, July.

[10] Rosindiyanto. (2012). Analisis Fleksibilitas Supply Chain Pada Perusahaan Dengan Sistem Produksi Berbasis Make To Stock di Pabrik Karung Rosella Baru Surabaya. Tekmapro : Journal of Industrial Engineering and Mangement, 2(1).

[11] Soejanto, I., \& Nursubiyantoro, E. (2013). Tingkat fleksibilitas supply chain berbasis make to stock. Prosiding Seminar Nasional Teknik Industri Waluyo Jatmiko UPN "Veteran" Jawa Timur, 30-35.

[12] Stevenson, M., \& Spring, M. (2007). Flexibility From a Supply Chain Perspective: Definition and Review. International Journal of Operations and Production Management, 27(7), 685-713. https://doi.org/10.1108/01443570710756956

[13] Sugiyono. (2010). Metode Penelitian Kuantitatif, Kualitatif dan $R \& D$. Alfabeta.

[14] Sumarni, N., \& Muharam, A. (2005). Budidaya Tanaman Cabai Merah.

[15] Swafford, P. M., Ghosh, S., \& Murthy, N. (2000). A Model of Global Supply Chain Agility and Its Impact on Competitive Performance. Proceedings of the 31st National DSI Meeting, 0520(404), 1037-1039. http://ciber.gatech.edu/papers/workingpaper/1999/99_ 00-26.pdf

[16] Tambunan, T. . (2003). Pekembangan Sektor Pertanian di Indonesia:beberapa isu penting. Ghalia Indonesia.

[17] Tubagus, L. S., Mangantar, M., \& Tawas, H. (2016). Analisis Rantai Pasokan (Supply Chain) Komoditas Cabai Rawit Di Kelurahan Kumelembuai Kota Tomohon. Jurnal Riset Ekonomi, Manajemen, Bisnis Dan Akuntansi, 4(2), 613-621. https://doi.org/10.35794/emba.v4i2.13117 